\title{
Hypothermia and Amiloride Preserve Energetics in a Neonatal Brain Slice Model
}

\author{
NICOLA J. ROBERTSON, KISHORE BHAKOO, BASANT K. PURI, A. DAVID EDWARDS, AND \\ I. JANE COX

\begin{abstract}
Department of Paediatrics, Division of Paediatrics, Obstetrics and Gynaecology [N.J.R., A.D.E.], Magnetic Resonance (Neonatal Research) Group, Clinical Sciences Centre N.J.R., A.D.E.], Stem Cell
\end{abstract} \\ Imaging Group, Clinical Sciences Centre [K.B.], Imaging Sciences Department [B.K.P., A.D.E., I.J.C.], \\ Division of Clinical Sciences, Hammersmith Hospital, Imperial College London, London W12 ONN, UK
}

\begin{abstract}
A period of secondary energy failure consisting of a decline in phosphocreatine/inorganic phosphate $(\mathrm{PCr} / \mathrm{Pi})$, a rise in brain lactate, and alkaline intracellular $\mathrm{pH}\left(\mathrm{pH}_{\mathrm{i}}\right)$ has been described in infants with neonatal encephalopathy. Strategies that ameliorate this energy failure may be neuroprotective. We hypothesized that a neonatal rat brain slice model undergoes a progressive decline in energetics, which can be ameliorated with hypothermia or amiloride. Interleaved phosphorus $\left({ }^{31} \mathrm{P}\right)$ and proton $\left({ }^{1} \mathrm{H}\right) \mathrm{mag}-$ netic resonance (MR) spectra were obtained from $350 \mu \mathrm{m}$ neonatal rat brain slices over $8 \mathrm{~h}$ in a bicarbonate buffer at $37^{\circ} \mathrm{C}$ and at $32^{\circ} \mathrm{C}$ in 7 - and $14-\mathrm{d}$ models. ${ }^{31} \mathrm{P}$ MR spectra were obtained with amiloride in a bicarbonate-free buffer at $37^{\circ} \mathrm{C}$ in the $14-\mathrm{d}$ model. Findings were similar in 7- and 14-d models. In the 14-d model, there was a Pi doublet structure corresponding to alkaline $\mathrm{pH}_{\mathrm{i}}$ values of $7.50 \pm 0.02$ and $7.21 \pm 0.04$. Compared with the stabilized baseline of 100 , at $5 \mathrm{~h} \mathrm{PCr} / \mathrm{Pi}$ was $65 \pm 6.3$ and lactate/NAA was $187 \pm 3$ at $37^{\circ} \mathrm{C}$, but $\mathrm{PCr} / \mathrm{Pi}$ and lactate/NAA were not significantly different from baseline at $32^{\circ} \mathrm{C}$. Nucleotide triphosphate $(\mathrm{NTP}) /$ phosphomonoester $(\mathrm{PME})$ was $0.93 \pm 0.23$ at $37^{\circ} \mathrm{C}$ and $1.81 \pm 0.21$ at $32^{\circ} \mathrm{C}$ at $5 \mathrm{~h}$. With amiloride exposure
\end{abstract}

\section{ABSTRACT}

in the 14-d model, baseline $\mathrm{pH}_{\mathrm{i}}$ values were $7.25 \pm 0.09$ and 6.98 \pm 0.02 and NTP/PME was $1.81 \pm 0.05$; these parameters were not significantly different at $5 \mathrm{~h}$. Our interpretation of these findings is that the brain slice model underwent secondary energy failure, which was delayed with hypothermia or amiloride. (Pediatr Res 58: 288-296, 2005)

$\quad$ Abbreviations
${ }^{\mathbf{1}} \mathbf{H}$, proton
KHB, Krebs Henseleit buffer
$\mathbf{M R}$, magnetic resonance
$\mathbf{M R S}$, magnetic resonance spectroscopy
$\mathbf{N a}^{+} / \mathbf{H}^{+}$transporter, sodium/proton transporter
$\mathbf{N E}$, neonatal encephalopathy
$\mathbf{N T P}$, nucleotide triphosphate
${ }^{31} \mathbf{P}$, phosphorus
$\mathbf{P C r}$, phosphocreatine
$\mathbf{p H}$, intracellular pH
$\mathbf{P i}_{\text {in inorganic phosphate }}$
$\mathbf{P M E}$, phosphomonoester

PME, phosphomonoester
Studies in term infants with neonatal encephalopathy (NE) suggest that, although antenatal or genetic factors might predispose some infants to perinatal brain injury $(1,2)$, events in the immediate perinatal period are important in neonatal brain injury (3). A consistent pattern of energy derangement has been observed by several groups in infants with $\mathrm{NE}$ due to intrapartum asphyxia using phosphorus $\left({ }^{31} \mathrm{P}\right)$ and proton $\left({ }^{1} \mathrm{H}\right)$ magnetic resonance (MRS), spectroscopy (4-7). ${ }^{31} \mathrm{P}$ and ${ }^{1} \mathrm{H}$

Received October 11, 2004; accepted November 30, 2004.

Correspondence: N.J. Robertson, FRCPCH, Ph.D., Perinatal Brain Repair Group, Department of Obstetrics and Gynaecology, University College London, 86-96 Chenies Mews, London WC1E 6HX, UK; e-mail: n.robertson@ucl.ac.uk

Supported by the Higher Education Funding Council for England, Imperial College London, Philips Medical Systems, and JEOL (UK) Ltd., which funded the $500 \mathrm{MHz}$ magnetic resonance spectroscopy facility under the Joint Research Equipment Initiative.

DOI: 10.1203/01.PDR.0000170899.90479.1E
MR spectra were often normal within the first few hours after resuscitation, but after $8-24 \mathrm{~h}$ there was a progressive decline in $\mathrm{PCr} / \mathrm{Pi}$ and rise in brain lactate despite adequate oxygenation and circulation in the infant. The nadir of the energetic disturbance was seen after 12-24 $\mathrm{h}$ and the magnitude of the fall in $\mathrm{PCr} / \mathrm{Pi}$ and rise in brain lactate correlated with the subsequent neurodevelopmental abnormality $(8,9)$. This sequence of events was termed "secondary energy failure" to distinguish it from the "primary" decline in PCr and ATP and rise in lactate seen during the insult in experimental animal models of hypoxia-ischemia (HI) (10,11). The biphasic pattern of energy failure during and after $\mathrm{HI}$ has been the cornerstone behind the realization that neuroprotective strategies might interrupt the cascade of irreversible injury if administered within hours of a perinatal insult (12), and the concept has been an important catalyst in the development of neuroprotection trials with moderate hypothermia (13-15). 
Brain $\mathrm{pH}_{\mathrm{i}}$ is alkaline during secondary energy failure. This phenomenon was first described in an experimental model in the early 1980s, where, despite the marked intracellular acidosis during $\mathrm{HI}$, brain $\mathrm{pH}_{\mathrm{i}}$ normalized within 15 min of reperfusion and subsequently increased above the control value (16). The $\mathrm{Na}^{+} / \mathrm{H}^{+}$transporter is responsible for brain $\mathrm{pH}_{\mathrm{i}}$ and cell volume regulation under physiologic conditions by extruding protons from and taking sodium up into cells (17). Excessive stimulation of the $\mathrm{Na}^{+} / \mathrm{H}^{+}$transporter after transient $\mathrm{HI}$ is thought to lead to deleterious effects in the cell, one of which is an alkaline $\mathrm{pH}_{\mathrm{i}}$. Amiloride is an inhibitor of the $\mathrm{Na}^{+} / \mathrm{H}^{+}$ transporter and has been shown in some studies to ameliorate reperfusion injury (18).

The precise relationship between brain $\mathrm{pH}_{\mathrm{i}}$ and injury severity has been studied in infants with NE during the period of secondary energy failure and during the first year after birth (19). The extent of the brain alkalosis in the first $2 \mathrm{wk}$ after birth was associated with the severity of brain injury on MR imaging, neurodevelopmental outcome at $1 \mathrm{y}$, and brain lactate/Cr. Brain alkalosis persisted for weeks in infants with a severe neurodevelopmental outcome and was associated with the development of cerebral atrophy. These observations suggest that brain $\mathrm{pH}_{\mathrm{i}}$ may be a marker or mechanism of brain injury severity. Indeed, mild acidosis (both extra- and intracellular) during reperfusion after transient $\mathrm{HI}$ protects the brain $(20,21)$; in a tissue culture model of cerebral ischemia, the prevention of rebound alkalosis using amiloride after in vitro $\mathrm{HI}$ delayed the onset of injury for as long as the cells remained acidotic (22).

Interestingly, in some term infants with NE two components of the Pi peak were observed (19); two Pi components have also been observed in preterm infants at term (23) and in experimental models studied at high magnetic field strength of $7 \mathrm{~T}$ (10). These data suggest that there may be a degree of $\mathrm{pH}_{\mathrm{i}}$ heterogeneity in vivo.

The $\mathrm{pH}_{\mathrm{i}}$ of the brain slices is generally more alkaline than extracellular $\mathrm{pH}$, in contrast to in vivo observations where brain $\mathrm{pH}_{\mathrm{i}}$ is more acid than extracellular $\mathrm{pH}(24,25)$. Compared with intact brain, slices have a lower ATP and PCr (26) with an increased production of lactate (27). The precise mechanisms leading to these metabolic differences between the brain slice and intact brain are unclear, but we considered that reduced high-energy phosphates and intracellular alkalosis suggests that brain slices may be undergoing a process similar to the secondary energy failure seen after transient $\mathrm{HI}$ in newborn infants (4-7).

We therefore studied the energetics of immature rat brain slices over time using MRS techniques specifically to assess whether the brain slice model develops intracellular alkalosis with a progressive decline in energetics, analogous to secondary energy failure. We hypothesized that any such change in energetics would be ameliorated by hypothermia or with amiloride, strengthening the analogy to secondary energy failure.

\section{MATERIALS AND METHODS}

As studies of electrocortical activity have suggested that the 14-d rat pup is the most suitable age for comparative studies in the term human infant (28), the 14-d brain slice model was used in the majority of experiments. Any gestational age effect on energy decline was checked in the 7-d model; however, as no difference was observed, amiloride studies were performed only in the 14-d model.

For the baseline studies, $\mathrm{KHB}$ containing $\mathrm{NaCl}(124 \mathrm{mM}), \mathrm{KCl}(5 \mathrm{mM})$, $\mathrm{KH}_{2} \mathrm{PO}_{4}(1.2 \mathrm{mM}), \mathrm{MgSO}_{4}(1.2 \mathrm{mM}), \mathrm{CaCl}_{2}(1.2 \mathrm{mM}), \mathrm{NaHCO}_{3}(26 \mathrm{mM})$, and D-glucose $(10 \mathrm{mM})$, equilibrated with $\mathrm{O}_{2} / \mathrm{CO}_{2}, 95 \% / 5 \%$ at $37^{\circ} \mathrm{C}$ and at a $\mathrm{pH}$ of 7.4-7.5 was used. Because the presence of bicarbonate and $\mathrm{CO}_{2}$ have been reported to interfere with the changes in $\mathrm{pH}_{\mathrm{i}}$ due to amiloride (29), a bicarbonate-free buffer, HEPES, was therefore used for the amiloride experiments. The HEPES buffer contained $20 \mathrm{mM} N$-(2-hydroxyethyl)piperazine- $N$ '(2-ethanesulfonic acid)/20 mM 4-(2-hydroxyethyl)piperazine-1-(2-ethanesulfonic acid sodium salt, $\mathrm{NaCl}(124 \mathrm{mM}), \mathrm{KCl}(3 \mathrm{mM}), \mathrm{KH}_{2} \mathrm{PO}_{4}(1.2 \mathrm{mM})$, $\mathrm{MgSO}_{4}(1.2 \mathrm{mM}), \mathrm{CaCl}_{2}(2.0 \mathrm{mM})$, and D-glucose $(10 \mathrm{mM})$. The HEPES medium was gassed with $100 \% \mathrm{O}_{2}$ throughout the study and maintained at $37^{\circ} \mathrm{C}$ and at a $\mathrm{pH}$ of $7.4-7.5$.

Brain slices from 14-d-old rat pups were perfused in a $500 \mathrm{MHz} \mathrm{MR}$ spectroscopy system for $8 \mathrm{~h}$ under the following conditions: i) at $37^{\circ} \mathrm{C}$ in $\mathrm{KHB}$; ii) at $32^{\circ} \mathrm{C}$ in $\mathrm{KHB}$; iii) at $37^{\circ} \mathrm{C}$ in HEPES buffer, and iv) with $1 \mathrm{mM}$ amiloride at $37^{\circ} \mathrm{C}$ in HEPES buffer. Brain slices from 7-d-old rat pups were perfused i) at $37^{\circ} \mathrm{C}$ in $\mathrm{KHB}$ and ii) at $32^{\circ} \mathrm{C}$ in $\mathrm{KHB}$. Interleaved ${ }^{31} \mathrm{P}$ and ${ }^{1} \mathrm{H}$ MR spectra were acquired in all studies in KHB. ${ }^{31} \mathrm{P}$ MR spectra only were acquired in the amiloride studies because of overlap of ${ }^{1} \mathrm{H}$ signals from HEPES buffer with the ${ }^{1} \mathrm{H}$ metabolite resonances of interest.

All studies used were done in accordance with the Home Office guidelines and were consistent with the Animals (Scientific Procedures) Act, 1986 (UK).

Preparation and maintenance of brain slices under control conditions at $37^{\circ} \boldsymbol{C}$ in $\mathbf{K H B}$. Brain slices, $350 \mu \mathrm{m}$ thick, were prepared from both cerebral hemispheres of 7- $(n=3)$ and 14-d $(n=3)$ Wistar rats of either sex using a McIlwain tissue chopper (Mickle Laboratory Engineering, Mill Works, Gomshall, Surrey, UK). For each experiment, two to five brains were used. Immediately after slices had been prepared they were placed in a flask containing $100 \mathrm{~mL}$ of $\mathrm{KHB}$ equilibrated with $\mathrm{O}_{2} / \mathrm{CO}_{2}, 95 \% / 5 \%$ at $37^{\circ} \mathrm{C}$ at a $\mathrm{pH}$ of 7.4-7.5. Slices were gently mixed and washed five times before decanting into a standard $15-\mathrm{mm}$ diameter NMR tube containing $10 \mathrm{~mL}$ of the gassed medium at $37^{\circ} \mathrm{C}$. The NMR tube was fitted with a polytetrafluorethylene insert carrying a custom-made superfusion apparatus (30).

The perfusion apparatus included two peristaltic pumps fitted with quickrelease pump heads to make up a complete nonrecirculating perfusion circuit. The superfusion rate was adjusted to $25-30 \mathrm{~mL} / \mathrm{min}$ to ensure gentle movement of the slice tissue and sufficient perturbation to prevent tissue clumping. The temperature of the slices was controlled at $37^{\circ} \mathrm{C}$ throughout the experiment by using the variable temperature control unit of the spectrometer and the heated water jacket for the perfusate. A third peristaltic pump controlled the rate of water flow through the water jacket; the temperature of the water in the water jacket was adjustable by using the water bath thermometer. The temperature of the KHB bathing the slices was monitored by a fiber-optic thermometer (Luxtron 3100, Luxtron, Santa Clara, CA). The pH of the KHB was monitored and maintained at around 7.5 throughout the study.

Initially, the slices were superfused at $37^{\circ} \mathrm{C}$ in KHB outside the bore of the magnet for 30-45 min. The apparatus was then placed within the bore of the magnet and one set of ${ }^{31} \mathrm{P}$ and ${ }^{1} \mathrm{H}$ NMR spectra in normal phosphate KHB was recorded. Pi was then omitted from the KHB and replaced with an equimolar amount of $\mathrm{KCl}$ to monitor the intracellular Pi concentration and the chemical shift of $\mathrm{Pi}$, which may be used as an indicator of $\mathrm{pH}_{\mathrm{i}}$ using a standard calibration curve (31).

Stabilization was defined as $1.5 \mathrm{~h}$ after slicing and approximately $30 \mathrm{~min}$ after omission of Pi from the buffer. Slices were then perfused for a further $6.5 \mathrm{~h}, 8 \mathrm{~h}$ from the time of slicing.

Preparation and maintenance of brain slices under hypothermic conditions. Brain slices, $350 \mu \mathrm{m}$ thick, were prepared from both cerebral hemispheres of 7- $(n=5)$ and 14-d $(n=4)$ Wistar rats of either sex. The temperature of $\mathrm{KHB}$ was maintained at $32^{\circ} \mathrm{C}$ throughout the study. All other factors were identical to the preparation and maintenance of brain slices under control conditions.

Preparation and maintenance of brain slices with HEPES and amiloride. Brain slices were prepared from 14-d $(n=5)$ Wistar rats of either sex and placed in a flask containing the nonbicarbonate buffer, HEPES. The HEPES medium was gassed with $100 \% \mathrm{O}_{2}$ throughout the study and maintained at $37^{\circ} \mathrm{C}$ and at a $\mathrm{pH}$ of 7.4-7.5. In two experiments, $1 \mathrm{mM}$ amiloride hydrochloride (Sigma Chemical, St. Louis, MO), initially dissolved in 50\% DMSO, was added to the HEPES medium. Again, the HEPES medium was gassed with $100 \% \mathrm{O}_{2}$ throughout the study and maintained at $37^{\circ} \mathrm{C}$ and at a $\mathrm{pH}$ of 7.4 . For all these experiments, all other factors were identical to the preparation and maintenance of brain slices under control conditions.

MR methods. ${ }^{1} \mathrm{H}$ and ${ }^{31} \mathrm{P}$ MR spectra were obtained at $500 \mathrm{MHz}$ (JEOL, Tokyo, Japan) ECP + $500 \mathrm{MHz}$ NMR spectrometer) using an $11.7 \mathrm{~T}$ super- 
conducting magnet (Oxford Instruments, Oxford, UK) and a dedicated Doty (Doty Scientific Inc., Columbia, SC) 15-mm high-resolution solution state probe with ${ }^{1} \mathrm{H}$ decouple/multinuclear observe.

Magnetic field inhomogeneities were reduced by shimming on the water signal. The proton $90^{\circ}$ pulse length was measured. Interleaved ${ }^{31} \mathrm{P}$ and ${ }^{1} \mathrm{H} \mathrm{MR}$ spectra were then acquired for the duration of the study in KHB buffer and ${ }^{31} \mathrm{P}$ MR spectra were acquired for studies using HEPES buffer. ${ }^{31} \mathrm{P}$ MR spectra were acquired using pulse-collect techniques. A pulse angle of $45^{\circ}$ was used with a repetition time of $1.8 \mathrm{~s}$. For each spectrum 256 transients were averaged. $\mathrm{T}_{1}$ values of individual metabolites were assumed to be constant throughout the study. ${ }^{1} \mathrm{H}$ MR spectra were acquired using a spin echo technique. The water was suppressed using presaturation techniques combined with $\mathrm{T}_{2}$ relaxation during evolution of the spin echo sequence. An echo time (TE) of $270 \mathrm{~ms}$ was used as a compromise between adequate water suppression, separation of lipid/lactate resonances, and metabolite signal loss due to $\mathrm{T}_{2}$ effects. The repetition time was $2.6 \mathrm{~s}$ and 256 transients were averaged for each spectrum.

${ }^{31} \mathrm{P}$ MR spectra were processed using linear prediction singular value decomposition-based backward linear projection method (order of operation was $16 ; 128$ points were sampled and 8 points were reconstructed) to reduce the contribution from the broad underlying resonance. A single exponential line broadening function of $20 \mathrm{~Hz}$ was then applied before Fourier transformation. Peak positions and integrals were measured using the system software (Delta 3.1, JEOL). On the basis of published chemical shift values, resonances were assigned PME, Pi, phosphodiesters (PDE), PCr, and NTP. The NTP peak area was measured from the sum of the composite peak areas of $\alpha, \beta$, and $\gamma$ NTP and therefore included any contribution from nucleoside diphosphates such as ADP.

Brain slice $\mathrm{pH}_{\mathrm{i}}$ was measured from the ${ }^{31} \mathrm{P}$ MR spectrum. The chemical shift difference $(\delta)$ of the Pi resonance(s) was referenced to the PCr peak, and the $\mathrm{pH}_{\mathrm{i}}$ value(s) were calculated at both temperatures using the HendersonHasselbach equation

$$
\mathrm{pH}_{\mathrm{i}}=6.75+\log \{(\mathrm{d}-3.27) /(5.69-\mathrm{d})\}
$$

where $\delta$ is the Pi shift relative to $\mathrm{PCr}(31)$. The mean $\mathrm{pH}_{\mathrm{i}}$ values were also adjusted for temperature of study (32).

${ }^{1} \mathrm{H}$ MR spectra were processed using a single exponential line broadening function of $2 \mathrm{~Hz}$ before Fourier transformation. An interactive baseline correction was applied before the peak positions and integrals were measured using the system software (Delta 3.1, JEOL). On the basis of published chemical shift values, resonances were assigned to choline-containing compounds (Cho), creatine plus phosphocreatine $(\mathrm{Cr}), N$-acetyl aspartate (NAA), and lactate (9).

Statistical analysis. All data in this study are presented as mean \pm SD. Statistical analyses of the data were performed using SPSS, version 10.1 for Windows (SPSS Inc., Chicago, IL). Parametric data were analyzed using $t$ tests. In one study, the sample size was two; because these data were obtained in an unbiased way from an underlying population that was normally distributed, it was legitimate to use $t$ tests for comparisons involving this sample.

The stabilization point when the initial brain slice spectral parameters were recorded was $1.5 \mathrm{~h}$ after slicing. The stabilization baseline was assigned the value of 100 and was constructed by averaging metabolite ratios acquired between 1.5 and $2.5 \mathrm{~h}$ after slicing. To demonstrate any change in metabolite ratios over time, subsequent ratios acquired at $5 \mathrm{~h}$ were compared with this averaged baseline value using confidence intervals. The changes in the NTP/ PME ratio over time for the three groups $\left(37^{\circ} \mathrm{C}, 32^{\circ} \mathrm{C}\right.$, and $1 \mathrm{mM}$ amiloride at $37^{\circ} \mathrm{C}$ ) were compared using a multivariate repeated measures model with a Bonferroni correction. Two tests of within-subjects contrasts were also performed.

\section{RESULTS}

None of the data sets were skewed and therefore parametric analytic tests were used. The assumption of equal variances was not always valid when using the $t$ test and, in these cases, an unequal variance modification was used.

Metabolite ratios values from 7 - and 14-d models acquired after stabilization in $\mathrm{KHB}$ at $37^{\circ} \mathrm{C}$ and $32^{\circ} \mathrm{C}$ are shown in Table 1. Representative ${ }^{31} \mathrm{P}$ and ${ }^{1} \mathrm{H}$ MR spectra from the 7 - and 14-d model at $37^{\circ} \mathrm{C}$ after stabilization in $\mathrm{KHB}$ are shown in Figure 1. Both the 7- and 14-d models demonstrated a high degree of metabolic integrity; mean $\mathrm{PCr} / \mathrm{Pi}$ was $>1.5$ and lactate/NAA was $<0.5$ in both models. NAA/Cr increased with increasing maturity $\left(p=0.064\right.$ at $37^{\circ} \mathrm{C}$ and $p<0.001$ at $32^{\circ} \mathrm{C}$ ). $\mathrm{PCr} / \mathrm{Pi}$ and NTP/PME were higher when the temperature was $32^{\circ} \mathrm{C}$ compared with $37^{\circ} \mathrm{C}$ in both the 7 - and $14-\mathrm{d}$ models, but this only reached significance for NTP/PME in the 7-d old model ( $p<0.01)$.

Metabolites ratios from the 14-d model acquired after stabilization in HEPES alone and HEPES with amiloride are also shown in Table 1. There were no significant differences in $\mathrm{PCr} / \mathrm{Pi}$ and NTP/PME in HEPES buffer compared with the stabilization values in KHB. After stabilization in HEPES with amiloride, NTP/PME was significantly increased but there was no significant difference in $\mathrm{PCr} / \mathrm{Pi}$ compared with values in HEPES alone and in KHB.

Brain slice $\boldsymbol{p H}_{\boldsymbol{i}}$. $\mathrm{pH}$ values from 7 and 14-d models acquired after stabilization in $\mathrm{KHB}$ at $37^{\circ} \mathrm{C}$ and $32^{\circ} \mathrm{C}$ and from the 14-d model in HEPES and HEPES with amiloride shown in Table 1 . In KHB buffer with Pi omitted there were two conponents of the $\mathrm{Pi}$ peak; the peaks were assigned $\mathrm{pH}_{\mathrm{i}}$ (1) and $\mathrm{pH}_{\mathrm{i}}$ (2) (most alkaline and least alkaline, respec-

Table 1. Metabolite ratios and $\mathrm{pH}_{i}$ values at stabilization (1.5 hours after slicing) in the 7-and 14 -day brain slice models at $37^{\circ} \mathrm{C}$ and $32^{\circ} \mathrm{C}$ and in the 14-day model in different buffers at $37^{\circ} \mathrm{C}$

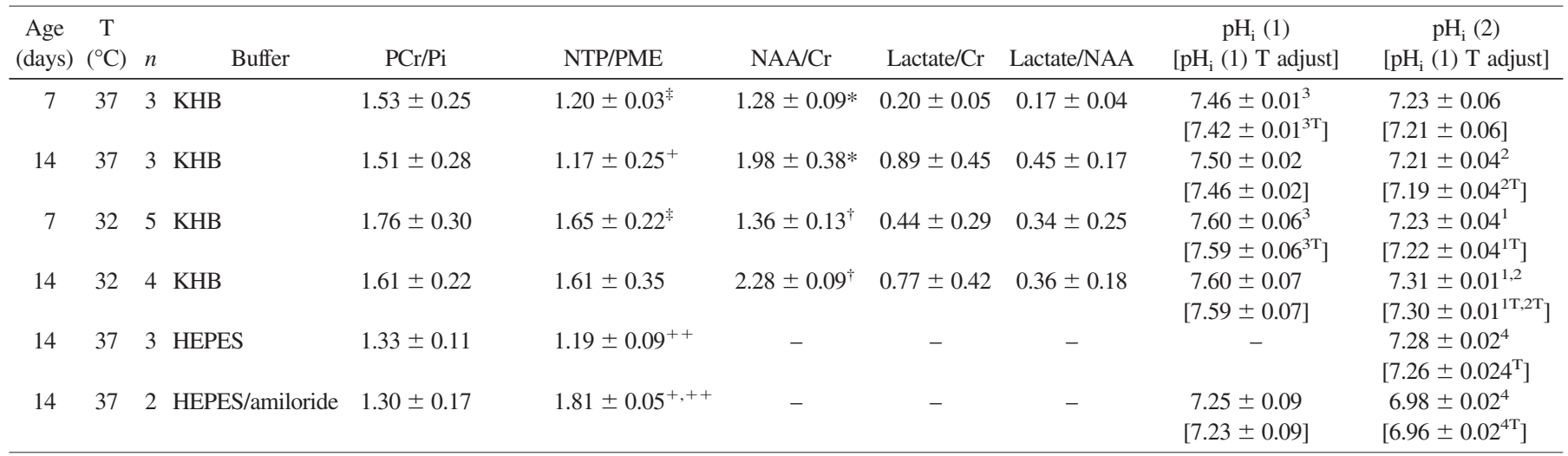

$* p=0.064(t=2.54, d f=4) ;{ }^{\dagger} p<0.001(t=10.61, d f=7) ;{ }^{\ddagger} p<0.01(t=4.51, d f=4.37$ (unequal variances) $) ;{ }^{+} p<0.05(t=3.40, d f=4) ;{ }^{++} p<$ $0.05(t=8.60, d f=3) .{ }^{1} p<0.01, t=4.31, d f=4.92$ (unequal variances) $;{ }^{2} p<0.05, t=4.23, d f=2.38$ (unequal variances); ${ }^{3} p<0.01, t=5.10, d f=$ 4.55 (unequal variances); ${ }^{4} p=0.001, t=12.73, d f=3 ;{ }^{1 \mathrm{~T}} p<0.01[p=0.0086], t=4.31, d f=4.92$ (unequal variances); ${ }^{2 \mathrm{~T}} p<0.05[p=0.0280], t=$ 4.66, $d f=2.38$ (unequal variances); ${ }^{3 \mathrm{~T}} p<0.005[p=0.0032], t=4.55, d f=6.19$ (unequal variances); ${ }^{4 \mathrm{~T}} p=0.001, t=12.73, d f=3$. 
tively). Brain $\mathrm{pH}_{\mathrm{i}}$ values were generally similar with increasing maturity at both $37^{\circ} \mathrm{C}$ and $32^{\circ} \mathrm{C}$, although $\mathrm{pH}_{\mathrm{i}}$ (2) was significantly more alkaline in the 7-d-old model compared with the 14 -d-old model at $32^{\circ} \mathrm{C}(p<0.01)$. There was a trend toward a more alkaline $\mathrm{pH}_{\mathrm{i}}$ at $32^{\circ} \mathrm{C}$ compared with $37^{\circ} \mathrm{C}$ in both the 7- and 14-d models, which reached significance for $\mathrm{pH}_{\mathrm{i}}(2)$ in the 14-d old model $(p<0.05)$ and for $\mathrm{pH}_{\mathrm{i}}(1)$ in the 7-d model $(p<0.01)$.

In HEPES alone, a single Pi peak at 7.28 was detected in the 14-d old model at $37^{\circ} \mathrm{C}$. In HEPES with amiloride a doublet Pi structure was detected, and $\mathrm{pH}_{\mathrm{i}}$ (2) was significantly less alkaline than the $\mathrm{pH}_{\mathrm{i}}$ in HEPES alone $(p=0.001)$.

Changes in brain slice energetics over time at $37^{\circ} \mathrm{C}$ and $32^{\circ} \mathrm{C}$ in 7- and 14-d models perfused with $\mathrm{KHB}$ with Pi omitted. Taking the stabilized baseline value at 100 for each metabolite ratio, the metabolite ratios at $5 \mathrm{~h}$ at $37^{\circ} \mathrm{C}$ and $32^{\circ} \mathrm{C}$ in the 14-d models are summarized in Table 2.

At $37^{\circ} \mathrm{C}, \mathrm{PCr} / \mathrm{Pi}$ was significantly reduced at $5 \mathrm{~h}$ in both the 7- and 14-d models compared with baseline (Fig. 2, $A$ and $B$ ). The value in the 14-d model at $5 \mathrm{~h}$ was not significantly different from $\mathrm{PCr} / \mathrm{Pi}$ in the 7-d model $(t=2.61 ; d f=4 ; p=$ $0.06)$. Lactate/NAA was significantly increased at $5 \mathrm{~h}$ in the 14-d model (Fig. 3) but was not significantly different from baseline in the 7-d model. NTP/PME was not significantly different from baseline at $5 \mathrm{~h}$ in both 7- and 14-d models (Table 2). $\mathrm{pH}$ values were unchanged at $5 \mathrm{~h}$ compared with baseline values in both the 14-d (Fig. 4) and 7-d models.

Effect of amiloride on changes in brain slice energetics over time at $37^{\circ} \mathrm{C}$. In the 14-d model, taking the stabilized baseline as 100, at $5 \mathrm{~h}$ the $\mathrm{PCr} / \mathrm{Pi}$ was 68 in HEPES alone and $59 \pm 11$ in HEPES with amiloride; these values lay outside the 99\% confidence interval of the stabilized baseline values.

Effect of hypothermia or amiloride on NTP/PME in the 14-d model. Considering the individual metabolite ratios in the slices prepared from 14-d neonatal rat pups in KHB buffer with $\mathrm{Pi}$ omitted, at $5 \mathrm{~h} \mathrm{NTP/PME}$ was higher at $32^{\circ} \mathrm{C}(1.81 \pm 0.21)$ than at $37^{\circ} \mathrm{C}(0.93 \pm 0.23, t=4.45, d f=5, p=0.01)$.

Comparing the NTP/PME ratio in KHB with Pi omitted and HEPES with amiloride, at $5 \mathrm{~h}$ the NTP/PME ratio was $0.93 \pm$ 0.23 in KHB and $1.88 \pm 0.23$ in HEPES with amiloride $(t=$ $3.51, d f=3, p=0.03$ ) (Figs. 5 and 6). The preservation of NTP/PME with amiloride $(1.88 \pm 0.23)$ at $5 \mathrm{~h}$ did not differ from that which occurred with hypothermia $(1.81 \pm 0.21, t=$ $0.30, d f=4, p>0.1$ ) (Fig. 6).

Repeated measure analysis using all data obtained over the $8 \mathrm{~h}$ demonstrated similar results. The three groups differed significantly $(F=62.67, d f=2,24, p<0.0001)$. The two tests of within-subject contrasts demonstrated that the $37^{\circ} \mathrm{C}$ and $32^{\circ} \mathrm{C}$ groups differed $(F=100.65, d f=1,12, p<0.0001)$ but that the $32^{\circ} \mathrm{C}$ and the $1 \mathrm{mM}$ amiloride at $37^{\circ} \mathrm{C}$ groups did not differ significantly $(F=0.76, d f=1,12, p=0.4)$.

\section{DISCUSSION}

Neonatal rat brain slices maintained for a number of hours showed changes in bioenergetics with time; under control conditions at $37^{\circ} \mathrm{C}$ neonatal brain slices were alkaline and underwent a gradual decline in $\mathrm{PCr} / \mathrm{Pi}$ and rise in lactate/NAA over $8 \mathrm{~h}$. Moderate hypothermia at $32^{\circ} \mathrm{C}$ delayed the decline in $\mathrm{PCr} / \mathrm{Pi}$ and rise in lactate/NAA. Brain slice $\mathrm{pH}_{\mathrm{i}}$ acidified on exposure to amiloride, both at baseline and at $5 \mathrm{~h}$. NTP/PME was preserved at lower temperatures and in slices exposed to amiloride, both at baseline and at $5 \mathrm{~h}$.

Our findings differ from those from a previous study of neonatal brain slice energetics over a prolonged period (33). ${ }^{31} \mathrm{P}$ and ${ }^{1} \mathrm{H}$ metabolite concentrations were unchanged for $>10$ $\mathrm{h}$ in a small number of calibration and comparison studies
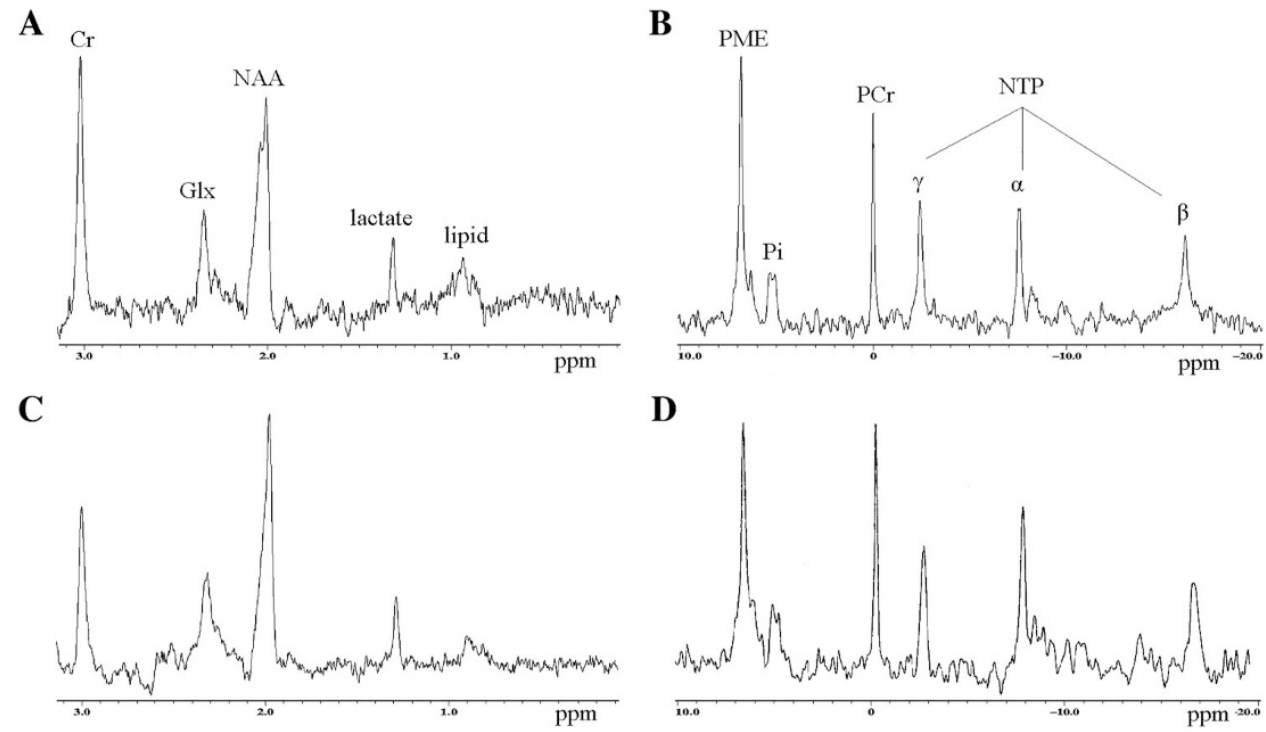

Figure 1. Representative ${ }^{1} \mathrm{H}$ and ${ }^{31} \mathrm{P}$ MR spectra at stabilization in the neonatal rat brain slice model at $37^{\circ} \mathrm{C}$. The slices were perfused with $\mathrm{KHB}$ with no external phosphate added. $(A, C){ }^{1} \mathrm{H}$ MR spectra from 7- and 14-d brain slice model, respectively. The peak area ratio lactate/NAA was $<0.5$ in both models. NAA was more prominent in the 14-d model, reflecting an increase with maturation. $(B, D){ }^{31} \mathrm{P}$ MR spectra from 7- and 14-d brain slice model, respectively. In both spectra, there were two components to the Pi peak. The PME peak was the most prominent resonance in the 7-d model whereas the PCr peak was most prominent in the 14-d spectrum. $\mathrm{Cr}$, creatine plus phosphocreatine; $G l x$, glutamine/glutamate; $N A A$, $N$-acetylaspartate. 
Table 2. Brain slice energetics, taking the stabilized baseline as 100, and pH values at 5 hours the 14-day brain slice models perfused with $\mathrm{KHB}$ with Pi omitted at $37^{\circ} \mathrm{C}$ and $32^{\circ} \mathrm{C}$ and in HEPES with and without amiloride at $37^{\circ} \mathrm{C}$

\begin{tabular}{ccclccccc}
\hline $\begin{array}{c}\text { Age } \\
\text { (days })\end{array}$ & $\begin{array}{c}\mathrm{T} \\
\left({ }^{\circ} \mathrm{C}\right)\end{array}$ & $n$ & & \multicolumn{1}{c}{ Buffer } & PCr/Pi & Lactate/NAA & NTP/PME & $\mathrm{pH}_{\mathrm{i}}(1)$ \\
\hline 7 & 37 & 3 & KHB & $40 \pm 12^{1}$ & $125 \pm 25$ & $62 \pm 9$ & $7.52 \pm 0.14$ & $7.21 \pm 0.04$ \\
14 & 37 & 3 & KHB & $65 \pm 6^{1}$ & $187 \pm 3^{1}$ & $79 \pm 20$ & $7.50 \pm 0.03$ & $7.22 \pm 0.01$ \\
7 & 32 & 5 & KHB & $96 \pm 15$ & $115 \pm 31$ & $89 \pm 16$ & $7.55 \pm 0.08$ & $7.28 \pm 0.07$ \\
14 & 32 & 4 & KHB & $107 \pm 27$ & $104 \pm 6$ & $101 \pm 26$ & $7.66 \pm 0.06$ & $7.33 \pm 0.07$ \\
14 & 37 & 1 & HEPES & $68^{1}$ & - & 87 & 7.18 \\
14 & 37 & 2 & HEPES/amiloride & $59 \pm 11^{1}$ & - & $113 \pm 31$ & $7.23 \pm 0.01$ & $7.06 \pm 0.05$ \\
\hline
\end{tabular}

${ }^{1}$ Value lay outside the $99 \%$ confidence interval of the stabilized baseline values.

using a perfusate free of inorganic phosphate; there is no obvious explanation for this difference.

Validity of brain slice model. There are some drawbacks to the brain slice model. Firstly, it is inevitable that some slices were lost during $8 \mathrm{~h}$ of perfusion and occasional slices were seen in the waste fluid. To correct for the decline in tissue volume we assigned the metabolite ratio at $1.5 \mathrm{~h}$ after slicing as $100 \%$ and compared subsequent ratios. Secondly, KHB and HEPES buffers were gassed with $95 \% \mathrm{O}_{2} / 5 \% \mathrm{CO}_{2}$ and $100 \%$ $\mathrm{O}_{2}$, respectively, which may have generated suboptimal conditions due to the associated increased production of oxygen free radicals (34). Thirdly, amiloride was dissolved in DMSO and brain slices were exposed to a concentration of $0.01 \%$ DMSO over $8 \mathrm{~h}$. Such a small concentration is unlikely to affect brain slice energetics, however, as DMSO is a free radical scavenger that in higher concentrations appears to preserve ATP after ischemia-induced damage in the liver (35), further studies should include controls exposed to DMSO alone to differentiate mechanisms of amiloride/DMSO treatment. Finally, the interrelationship of $\mathrm{PCr}$, creatine kinase equilibrium, and $\mathrm{pH}$ is complex (36), so a comparison of $\mathrm{PCr} / \mathrm{Pi}$ at different $\mathrm{pH}$ values needs caution. It was not possible to measure $\mathrm{PCr} / \mathrm{Pi}$ within different $\mathrm{pH}$ compartments from a given spectrum. However, because the $\mathrm{pH}$ was constant over time at $32^{\circ} \mathrm{C}$ and $37^{\circ} \mathrm{C}$ in both the 7- and $14-\mathrm{d}$ models, we argue that it is valid to interpret a change in $\mathrm{PCr} / \mathrm{Pi}$ during a time course study.

Interpretation of the changes in bioenergetics under control conditions as secondary energy failure. We speculate that primary energy failure occurs during decapitation and slicing of the brain slices. This phenomenon, "primary energy failure," associated with brain slice preparation was demonstrated more than $50 \mathrm{y}$ ago; after depletion of PCr and ATP during slicing, sliced brain tissue was able to resynthesize high-energy phosphates to around two-thirds of in vivo levels when placed in saline with glucose and oxygen as substrates (26). These experiments demonstrated that stable levels of PCr and ATP could be maintained for at least $2 \mathrm{~h}$ after preparation and that, during this time, the tissue was responsive to the metabolic demands of electrical pulses (37).

We speculate that the secondary decline in the bioenergetic status of brain slices that we have observed in our model over $8 \mathrm{~h}$ under control conditions is "secondary energy failure." Secondary energy failure is a concept rather than a mechanism; although there are close associations between secondary energy failure and histologic damage (38), the precise mechanisms leading to secondary energy failure are unclear. It is likely that neurotoxic cascades are activated by both HI associated with the slice preparation and trauma to the cut edges of the brain tissue. We demonstrated that $\mathrm{PCr} / \mathrm{Pi}$ declined and lac/NAA increased progressively over 6-8 h under control conditions despite adequate substrate and oxygen supply. These findings are similar to those that define the period of secondary energy failure in term infants after perinatal $\mathrm{HI}$. The reduction in $\mathrm{PCr} / \mathrm{Pi}$ and increase in lactate concentrations are thought to result from mitochondrial damage leading to impaired oxidative phosphorylation. The consequent rise in the intramitochondrial $\mathrm{NADH} / \mathrm{NAD}^{+}$ratio inhibits pyruvate dehydrogenase activity, resulting in less pyruvate entering the Krebs cycle and an increased conversion of pyruvate to lactate in the cytosol. The rate of lactate production is further increased by the alkaline $\mathrm{pH}_{\mathrm{i}}$ and its effect on the $\mathrm{pKa}$ of phosphofructokinase. The reduction in NAA reflects declining levels of neuronal viability and density.

The decline in energetics of the brain slice model is unlikely to be due to chronic ischemia, as we ensured constant perfusion and steady and gentle movement of slices, slices were of the optimal slice thickness to allow adequate perfusion of glucose and oxygen $\left(<400 \mu \mathrm{m}\right.$ thick), and the brain slice $\mathrm{pH}_{\mathrm{i}}$ was alkaline.

Although the metabolic parameters during the evolution of secondary energy failure are similar in vivo and in the brain slice model, there are a number of factors that limit the strength of a brain slice/in vivo comparison. The reduced oxygen consumption of brain slices $(40 \%$ of in vivo brain) $(39,40)$ may be due to the absence of spontaneous neural activity in the preparation rather than a defect in the mitochondrial electron transport chain and a decreased oxygen uptake. In addition, the severity of the $\mathrm{HI}$ and traumatic insult in the brain slice model is profound; coupled with the lack of circulating trophic factors, the decline in energetics may be accelerated in the slice model.

Comparison of the effects of amiloride and hypothermia on brain slice energetics and $\boldsymbol{p H}_{\boldsymbol{i}}$. NTP/PME was preserved over time in brain slices exposed to both amiloride and hypothermia. PCr/Pi levels were unchanged compared with baseline in those exposed to hypothermic conditions, whereas $\mathrm{PCr} / \mathrm{Pi}$ levels were significantly lower at $5 \mathrm{~h}$ on exposure to amiloride. Brain slice $\mathrm{pH}_{\mathrm{i}}$ at baseline and at $5 \mathrm{~h}$ was alkaline during hypothermia and acidic during exposure to amiloride. We were unable to measure relevant ${ }^{1} \mathrm{H}$ MR spectra during exposure to amiloride because of spectral overlap with resonances from the buffer, so a comparison of changes in lactate/NAA was not possible. 


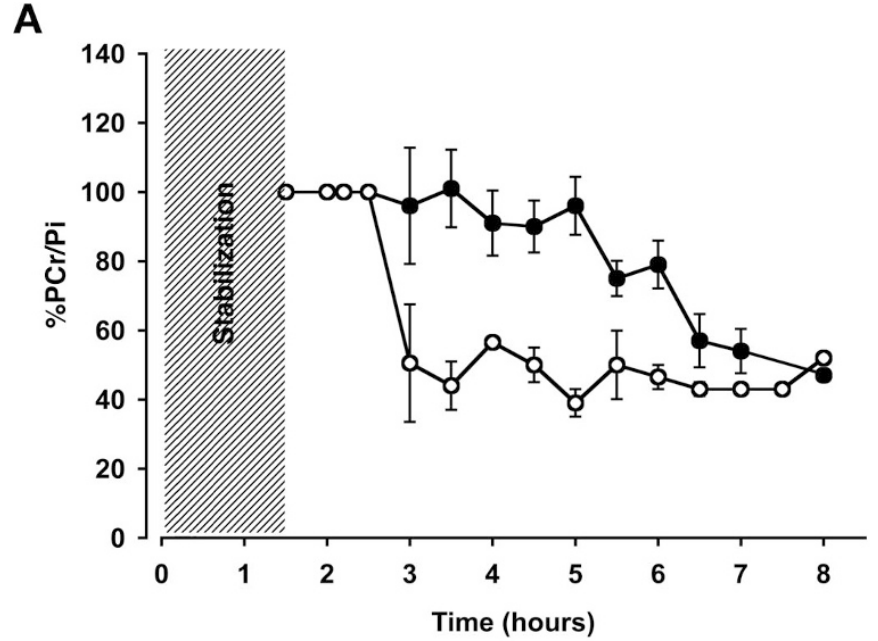

B

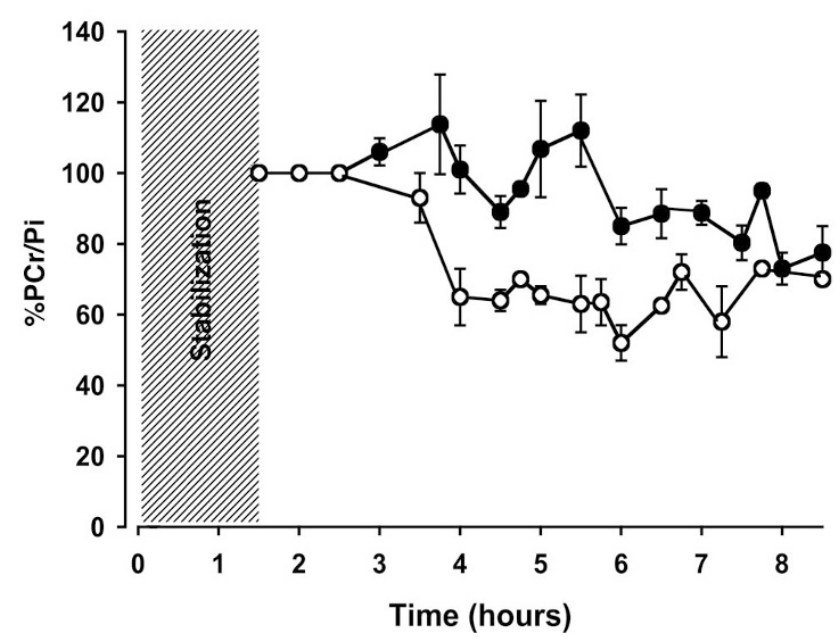

Figure 2. Changes in $\mathrm{PCr} / \mathrm{Pi}$ over $8 \mathrm{~h}$ at $37^{\circ} \mathrm{C}$ (open circles; $n=3$ ) and $32^{\circ} \mathrm{C}$ (closed circles; $n=4$ ) in $(A)$ the 7 -d and $(B)$ the 14-d neonatal rat pup brain slices perfused with KHB with no external phosphate added. A stabilization baseline value, assigned to 100 , was achieved averaging metabolite ratios acquired between 1.5 and $2.5 \mathrm{~h}$ after slicing. After $5 \mathrm{~h}, \mathrm{PCr} / \mathrm{Pi}$ at $37^{\circ} \mathrm{C}$ lay outside the $99 \%$ confidence interval $(p<0.01)$ of baseline value, but at $32^{\circ} \mathrm{C}$ was not significantly different from baseline in both ages of model.

The bioenergetic effects of hypothermia and amiloride differed in terms of $\mathrm{pH}_{\mathrm{i}}$ and $\mathrm{PCr} / \mathrm{Pi}$, yet both led to a preservation of NTP/PME over time. The mechanisms leading to preservation of energetics may therefore differ, particularly as hypothermia was associated with an alkalosis in brain slice $\mathrm{pH}_{\mathrm{i}}$ whereas exposure to amiloride was associated with a relative acidosis.

Hypothermia. We demonstrated that the decline in $\mathrm{PCr} / \mathrm{Pi}$ and rise in lactate/NAA were slower at $32^{\circ} \mathrm{C}$ compared with $37^{\circ} \mathrm{C}$ in both the 7 and 14-d brain slice models. A previous study in neonatal rat brain slices demonstrated that mild hypothermic conditions improved beta-ATP recovery after in vitro ischemia, but metabolites were measured for only about $2 \mathrm{~h}$ after the second insult so the effect on secondary energy failure could not be assessed (41).

In our study, the ameliorating effects of moderate hypothermia on the secondary decline in $\mathrm{PCr} / \mathrm{Pi}$ and rise in lactate/NAA

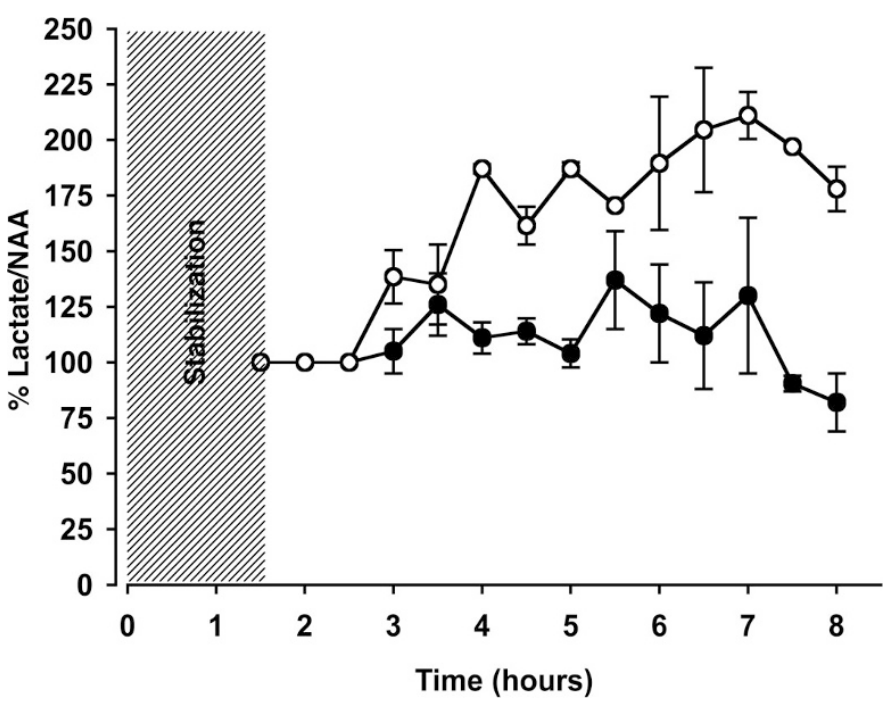

Figure 3. Changes in lactate/NAA over $8 \mathrm{~h}$ at $37^{\circ} \mathrm{C}$ (open circles; $n=3$ ) and $32^{\circ} \mathrm{C}$ (closed circles; $n=4$ ) in 14-d neonatal rat pup brain slices perfused with KHB with no external phosphate added. After $5 \mathrm{~h}$, lactate/NAA was outside the $99.9 \%$ confidence interval $(p<0.001)$ of baseline value at $37^{\circ} \mathrm{C}$ but was not significantly different from baseline at $32^{\circ} \mathrm{C}$.

in brain slices were similar to the effects of moderate hypothermia seen in experimental models of transient HI, where $12 \mathrm{~h}$ of cooling in the neonatal piglet reduced the delayed impairment in cerebral energy metabolism and reduced histologic injury $(42,43)$. A previous neonatal rat brain slice study demonstrated that both mild hypothermic and hypercarbic conditions applied after in vitro ischemia (following recovery from slicing) delayed the normalization of brain slice $\mathrm{pH}_{\mathrm{i}}$. When these postischemic perturbations were applied in isolation, there was an improvement in recovery of beta-ATP (41). The mechanisms leading to more favorable slice energetics in this experimental model may thus also be associated with a sustained mildly acidotic $\mathrm{pH}_{\mathrm{i}}$ during the postischemic phase.

The protective effects of hypothermia may include a reduction in the delayed increase in extracellular glutamate (44), a decreased production of nitric oxide (45), a reduction in the number of depolarizations in injured but viable tissue (46), and a reduction in the number of cells undergoing apoptosis (47). In addition, a $5^{\circ} \mathrm{C}$ decrease in brain slice temperature may offer neuroprotection by enhancing the maintenance of brain ATP concentrations. A linear relationship exists between brain energy utilization rate and brain temperature; specifically, a $1^{\circ} \mathrm{C}$ reduction in brain temperature from normothermic values of $37^{\circ} \mathrm{C}$ leads to a $5.3 \%$ reduction in the brain energy utilization rate (48). Therefore, a $26.5 \%$ reduction in cerebral energy utilization that accompanied a $5^{\circ} \mathrm{C}$ decrease in brain temperature in our brain slice studies may explain the observed preservation in $\mathrm{PCr} / \mathrm{Pi}$ and NTP/PME. A reduction of ATP is the hallmark of cerebral energy failure and is critical for initiating the cascade of cellular events such as loss of ionic gradients (49), release of excitatory neurotransmitters (44), and elevated intracellular calcium (50).

Amiloride. The presence of amiloride in the HEPES buffer acidified brain slice $\mathrm{pH}_{\mathrm{i}}$; this was likely to be due to inhibition of the activated $\mathrm{Na}^{+} / \mathrm{H}^{+}$transporter. The excessive activation 


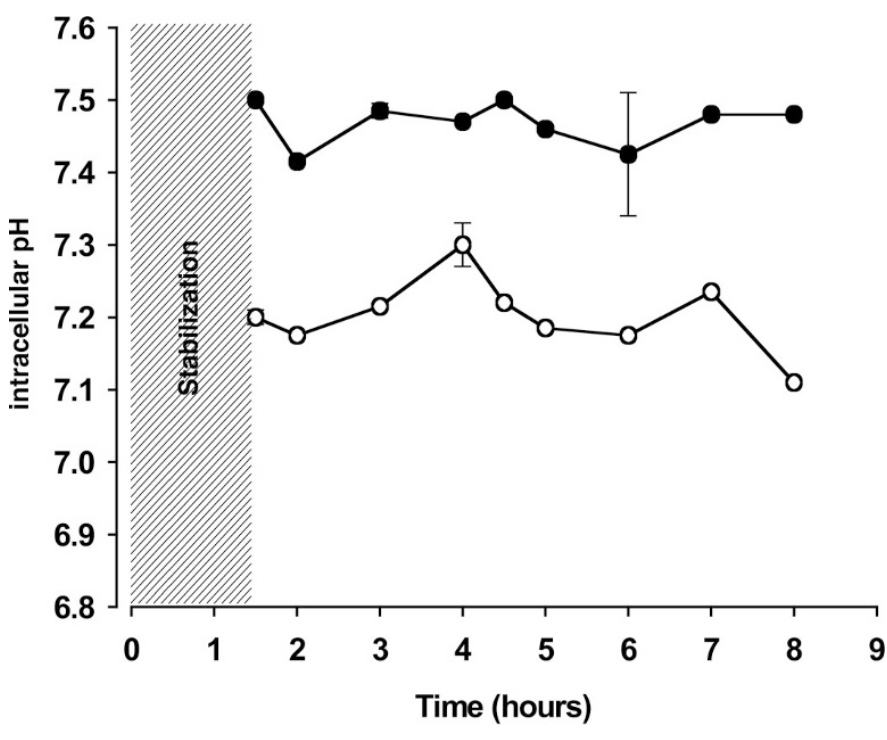

Figure 4. Representative $\mathrm{pH}_{\mathrm{i}}$ values from the two Pi peak components of the 14-d brain slice model at $37^{\circ} \mathrm{C}$ over $8 \mathrm{~h}$. There was clear $\mathrm{pH}_{\mathrm{i}}$ heterogeneity, as shown by $\mathrm{pH}$ (1) (open circles) and $\mathrm{pH}$ (2) (closed circles). No change in these $\mathrm{pH}_{\mathrm{i}}$ values occurred throughout the study.

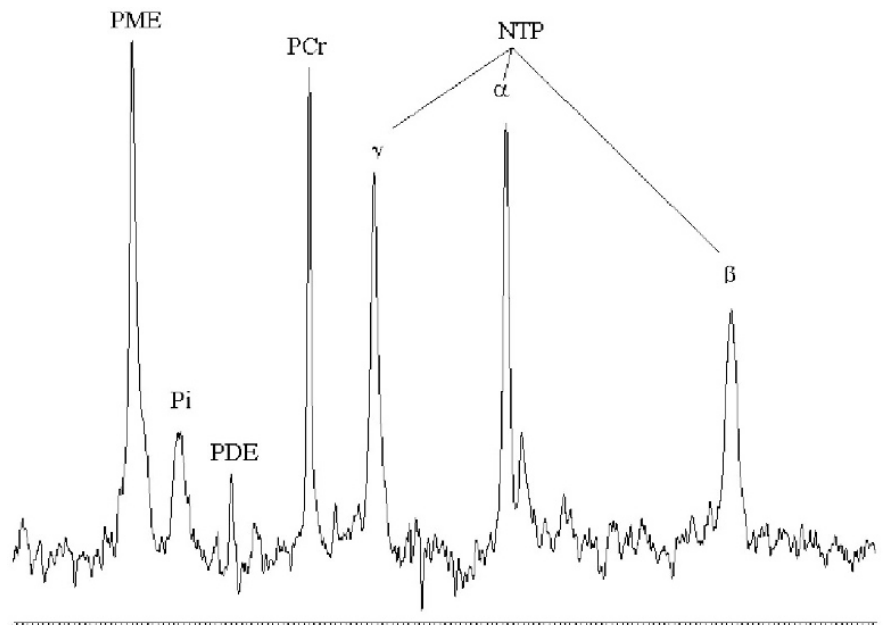

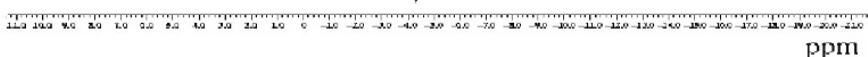

Figure 5. A representative ${ }^{31} \mathrm{P}$ MR spectrum of $14-\mathrm{d}$ neonatal rat brain slices in oxygenated HEPES buffer with $1 \mathrm{mM}$ amiloride $\mathrm{HCl} 5 \mathrm{~h}$ after slice preparation. Mean NTP/PME was 1.88 .

of the $\mathrm{Na}^{+} / \mathrm{H}^{+}$transporter which is triggered by the intracellular acidosis of $\mathrm{HI}$ restores physiologic $\mathrm{pH}_{\mathrm{i}}$ by extruding $\mathrm{H}^{+}$. Although exposure of brain slices to amiloride had no effect on the decline in $\mathrm{PCr} / \mathrm{Pi}$ at $5 \mathrm{~h}$ compared with HEPES alone or $\mathrm{KHB}$ at $37^{\circ} \mathrm{C}$, NTP/PME was higher at $5 \mathrm{~h}$ in brain slices exposed to amiloride at $37^{\circ} \mathrm{C}$ compared with those slices exposed to normal HEPES buffer with no added amiloride and those in KHB. The preservation of NTP/PME was similar to that in those slices maintained under hypothermic conditions.

One of the mechanisms of neuroprotection by amiloride may be related to the change in $\mathrm{pH}_{\mathrm{i}}$. An alkaline $\mathrm{pH}_{\mathrm{i}}$ may exacerbate injury during the evolution of secondary energy failure by the following mechanisms: i) Exacerbation of excitotoxic neuronal

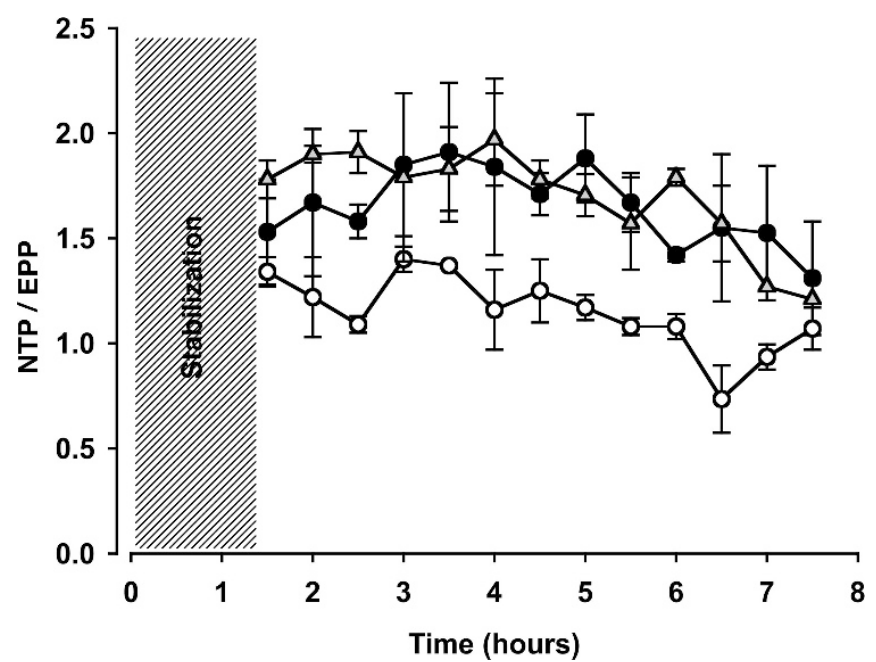

Figure 6. NTP/PME levels over $8 \mathrm{~h}$ in 14-d slices perfused with oxygenated HEPES buffer alone at $37^{\circ} \mathrm{C}$ (open circles; $n=3$ ), KHB with no external phosphate added at $32^{\circ} \mathrm{C}$ (closed circles; $n=4$ ), and with HEPES buffer with $1 \mathrm{mM}$ amiloride added at $37^{\circ} \mathrm{C}$ (open triangles; $n=2$ ). The preservation in NTP/PME was similar in the amiloride-exposed slices and the slices exposed to hypothermic conditions.

injury due to increased $\mathrm{N}$-methyl-D-aspartate activation at alkaline $\mathrm{pH}(51,52)$ and activation of phospholipases and proteases, which have an alkaline $\mathrm{pKa}(53)$. Inhibition of $\mathrm{Na}^{+} / \mathrm{H}^{+}$ exchange has been shown to block phospholipase activation in the ischemic/reperfused rat cerebral cortex as a consequence of its stabilizing effect on acidotic $\mathrm{pH}_{\mathrm{i}}$ and preventing alkalosis (54). ii) Alteration of the delicate balance of pro- and antiapoptotic triggers in mitochondria. Alkalinization has been shown to: a) activate Bax (a pro-apoptotic protein), inducing its mitochondrial translocation (55); b) inhibit the import of ADP into mitochondria, which impairs the synthesis of ATP (56); and c) transform the mitochondrial permeability transition pore into a high-conductance state, a critical step leading to cell commitment to death (57). Alkalinization has been described as a critical trigger in the apoptotic process (55).

Further mechanisms of neuroprotection by amiloride may relate to a reduction in energy consumption and calcium influx into the cell. For example, as well as influencing $\mathrm{pH}_{\mathrm{i}}$, the excessive action of the $\mathrm{Na}^{+} / \mathrm{H}^{+}$transporter after $\mathrm{HI}$ results in an increase in intracellular $\mathrm{Na}^{+}$concentration and subsequent activation of the $\mathrm{Na}^{+} / \mathrm{K}^{+}$ATPase, with a consecutive increase in energy consumption. The high intracellular $\mathrm{Na}^{+}$level contributes to activate the sarcolemmal $\mathrm{Na}^{+} / \mathrm{Ca}^{++}$antiporter, which leads to raised intracellular $\mathrm{Ca}^{++}(17,58)$. A variety of deleterious effects result from calcium overload, including mitochondrial accumulation of calcium, activation of proteolytic enzymes, free radical production, and lipolysis. Amiloride inhibits the $\mathrm{Na}^{+} / \mathrm{H}^{+}$transporter and the $\mathrm{Na}^{+} / \mathrm{Ca}^{++}$antiporter, potentially leading to an attenuation of the harmful consequences of excessive $\mathrm{Na}^{+} / \mathrm{H}^{+}$transporter activity. In addition, the favorable brain slice energetics seen with amiloride exposure in our study may be due to a direct effect on NMDA receptors, either in addition to or independent of its effect on the $\mathrm{Na}^{+} / \mathrm{H}^{+}$exchanger (55-59). 


\section{CONCLUSION}

We have demonstrated that neonatal brain slices are alkaline and undergo a gradual decline in $\mathrm{PCr} / \mathrm{Pi}$ and rise in lactate/ NAA over $8 \mathrm{~h}$ under control conditions at $37^{\circ} \mathrm{C}$. Our interpretation is that the brain slice model replicates secondary energy failure after a primary insult during decapitation and slicing of the tissue and that the resuscitation and reperfusion phases occurred when slices were placed in oxygenated KHB. Moderate hypothermia delayed the decline in $\mathrm{PCr} / \mathrm{Pi}$ and rise in lactate/NAA, an effect typical of secondary energy failure. Up-regulation of the $\mathrm{Na}^{+} / \mathrm{H}^{+}$transporter was implicated in the production of brain slice alkalosis, as amiloride, an inhibiter of the $\mathrm{Na}^{+} / \mathrm{H}^{+}$transporter, acidified brain slice $\mathrm{pH}_{\mathrm{i}}$. A preservation of NTP/PME was observed at lower temperatures and in slices exposed to amiloride. This preliminary observation in neonatal rat brain slices suggests that a delay in the $\mathrm{pH}_{\mathrm{i}}$ recovery or a more acidic $\mathrm{pH}_{\mathrm{i}}$ after $\mathrm{HI}$ was neuroprotective and suggests that studies examining the neuroprotective effects of amiloride after HI should be assessed in experimental models in vivo.

\section{REFERENCES}

1. Grether JK, Nelson KB 1997 Maternal infection and cerebral palsy in infants of normal birth weight. JAMA 278:207-211

2. Badawi N, Kurinczuk JJ, Keogh JM, Alessandri LM, O'Sullivan F, Burton PR, Pemberton PJ, Stanley FJ 1998 Antepartum risk factors for newborn encephalopathy: the Western Australian case-control study. BMJ 317:1549-1553

3. Cowan F, Rutherford M, Groenendaal F, Eken P, Mercuri E, Bydder GM, Meiners LC, Dubowitz LM, de Vries LS 2003 Origin and timing of brain lesions in term infants with neonatal encephalopathy. Lancet 361:736-742

4. Hope PL, Costello AM, Cady EB, Delpy DT, Tofts PS, Chu A, Hamilton PA, Reynolds EO, Wilkie DR 1984 Cerebral energy metabolism studied with phosphorus NMR spectroscopy in normal and birth-asphyxiated infants. Lancet 2:366-370

5. Younkin DP, Delivoria-Papadopoulos M, Leonard JC, Subramanian VH, Eleff S, Leigh JS Jr, Chance B 1984 Unique aspects of human newborn cerebral metabolism evaluated with phosphorus nuclear magnetic resonance spectroscopy. Ann Neurol 16:581-586

6. Laptook AR, Corbett RJ, Uauy R, Mize C, Mendelsohn D, Nunnally RL 1989 Use of ${ }^{31} \mathrm{P}$ magnetic resonance spectroscopy to characterize evolving brain damage after perinatal asphyxia. Neurology 39:709-712

7. Martin E, Buchli R, Ritter S, Schmid R, Largo RH, Boltshauser E, Fanconi S, Duc G, Rumpel H 1996 Diagnostic and prognostic value of cerebral ${ }^{31} \mathrm{P}$ magnetic resonance spectroscopy in neonates with perinatal asphyxia. Pediatr Res 40:749-758

8. Roth SC, Edwards AD, Cady EB, Delpy DT, Wyatt JS, Azzopardi D, Baudin J, Townsend J, Stewart AL, Reynolds EO 1992 Relation between cerebral oxidative metabolism following birth asphyxia and neurodevelopmental outcome and brain growth at one year. Dev Med Child Neurol 34:285-295

9. Hanrahan JD, Cox IJ, Azzopardi D, Cowan FM, Sargentoni J, Bell JD, Bryant DJ, Edwards AD 1999 Relation between proton magnetic resonance spectroscopy within 18 hours of birth asphyxia and neurodevelopment at 1 year of age. Dev Med Child Neurol 41:76-82

10. Lorek A, Takei Y, Cady EB, Wyatt JS, Penrice J, Edwards AD, Peebles D, Wylezinska M, Owen-Reece H, Kirkbride V, Cooper C, Aldridge RF, Roth SC, Brown G, Delpy DT, Reynolds EOR 1994 Delayed ('secondary') cerebral energy failure after acute hypoxia-ischaemia in the newborn piglet: continuous 48-hour studies by ${ }^{31}$ phosphorus magnetic resonance spectroscopy. Pediatr Res 36:699-706

11. Penrice J, Lorek A, Cady EB, Amess P, Wylezinska M, Cooper CE, D'Souza P, Brown GC, Kirkbride V, Edwards AD, Wyatt JS, Reynolds EO 1997 Proton magnetic resonance spectroscopy of the brain during acute hypoxia-ischemia and delayed cerebral energy failure in the newborn piglet. Pediatr Res 41:795-802

12. Taylor DL, Edwards AD, Mehmet H 1999 Oxidative metabolism, apoptosis and perinatal brain injury. Brain Pathol 9:93-117

13. Eicher DJ, Wagner CL, Katikaneni LP, Hulsey TC, Bass WT, Kaufman DA, Horgan MJ, Languani S, Bhatia JJ, Givelichian LM, Sankaran K, Yager JY 2005 Moderate hypothermia in neonatal encephalopathy: efficacy outcomes. Pediatr Neurol 32:11-17

14. Gluckman PD, Wyatt JS, Azzopardi D, Ballard R, Edwards AD, Ferriero DM, Polin RA, Robertson CM, Thoresen M, Whitelaw A, Gunn AJ 2005 Selective head cooling with mild systemic hypothermia after neonatal encephalopathy: multicentre randomized trial. Lancet 365:663-670

15. Shankatan S, Laptook A, Ehrenkranz R, Tyson J, McDonald S, Donavan E, et al 2005 Reduction in death or moderate/severe disability by whole body hypothermia for hypoxic-ischemic encephalopathy. Pediatr Res 57:1548

16. Mabe H, Blomqvist P, Siesjo BK 1983 Intracellular $\mathrm{pH}$ in the brain following transient ischaemia. J Cereb Blood Flow Metab 3:109-114
17. Masereel B, Pochet L, Laeckmann D 2003 An overview of inhibitors of $\mathrm{Na}\left({ }^{+}\right) / \mathrm{H}\left({ }^{+}\right)$ exchanger. Eur J Med Chem 38:547-545

18. Piper HM, Balser C, Ladilov YV, Schafer M, Siegmund B, Ruiz-Meana M, GarciaDorado D 1996 The role of $\mathrm{Na}^{+} / \mathrm{H}^{+}$exchange in ischemia-reperfusion. Basic Res Cardiol 91:191-202

19. Robertson NJ, Cowan FM, Cox IJ, Edwards AD 2002 Brain alkaline intracellular pH after neonatal encephalopathy. Ann Neurol 52:732-742

20. Simon RP, Niro M, Gwinn R 1993 Brain acidosis induced by hypercarbic ventilation attenuates focal ischaemic injury. J Pharmacol Exp Ther 267:1428-1431

21. Vannucci RC, Towfighi J, Bruchlacher RM, Vannucci SJ 2001 Effect of extreme hypercapnia on hypoxic-ischaemic brain damage in the immature rat. Pediatr Res 49:799-803

22. Vornov JJ, Thomas AG, Jo D 1996 Protective effects of extracellular acidosis and blockade of sodium/hydrogen ion exchange during recovery from metabolic inhibition in neuronal tissue culture. J Neurochem 67:2379-2389

23. Robertson NJ, Kuint J, Counsell SJ, Rutherford TA, Coutts GA, Cox IJ, Edwards AD 2000 Characterization of cerebral white matter damage in preterm infants using ${ }^{1} \mathrm{H}$ and ${ }^{31} \mathrm{P}$ magnetic resonance spectroscopy. J Cereb Blood Flow Metab 20:1446-1456

24. LaManna JC, Griffith JK, Cordisco BR, Lin CW, Lust WD 1992 Intracellular pH in rat brain in vivo and in brain slices. Can J Physiol Pharmacol 70:S269-277

25. Lin CW, Kalaria RN, Kroon SN, Bae JY, Sayre LM, LaManna JC 1996 The amiloride-sensitive $\mathrm{Na}^{+} / \mathrm{H}^{+}$exchange antiporter and control of intracellular $\mathrm{pH}$ in hippocampal brain slices. Brain Res 731:108-113

26. McIlwain H, Buchel L, Cheshire JD 1951 The inorganic phosphate and phosphocreatine of brain especially during metabolism in vitro. J Biochem (Tokyo) 48:12-20

27. Rolleston FS, Newsholme EA 1967 Control of glycolysis in cerebral cortex slices. Biochem J 104:524-533

28. Deza L, Eidleberg E 1967 Development of cortical electrical activity in the rat. Exp Neurol 17:425-438

29. Whittingham TS, Warman E, Assaf H, Sick TJ, LaManna JC 1989 Manipulating the intracellular environment of hippocampal slices: $\mathrm{pH}$ and high-energy phosphates. J Neurosci Methods 28:83-91

30. Bachelard H, Cox DW, Feeney J, Morris P 1985 Nuclear magnetic resonance studies of carbohydrate metabolism in vivo. Biochem Soc Trans 13:835-839

31. Taylor DJ, Bore PJ, Styles P, Gadian DG, Radda GK 1983 Bioenergetics of intact human muscle. A ${ }^{31} \mathrm{P}$ nuclear magnetic resonance study. Molec Biol Med 1:77-94

32. Kost GJ $1990 \mathrm{pH}$ standardisation for phosphorus-31 magnetic resonance heart spectroscopy at different temperatures. Magn Reson Med 14:496-506

33. Espanol MT, Litt L, Yang GY, Chang LH, Chan PH, James TL, Weinstein PR 1992 Tolerance of low intracellular $\mathrm{pH}$ during hypercapnia by rat cortical brain slices: A 31P/1H NMR study. J Neurochem 59:1820-1828

34. Saugstad OD 1996 Mechanisms of tissue injury by oxygen radicals: implications for neonatal disease. Acta Paediatr 85:1-4

35. Chiappa A, Makuuchi M, Zbar AP, Biella F, Bellomi M, Biffi R, Bertani E, Vezzoni A, Crosta C, Andreoni B 2003 Effects of the free radical scavenger dimethyl sulphoxide on experimental normothermic ischaemia of the liver. Dig Surg 20:238245

36. Kemp GJ 1997 Physiological constraints on changes in $\mathrm{pH}$ and phosphorus metabolite concentrations in ischemically exercising muscle: implications for metabolic control and for the interpretation of 31P-magnetic resonance spectroscopic studies. MAGMA $5 \cdot 231-241$

37. Bachelard H, Mcllwain H 1985 Biochemistry and the central nervous system. Churchill Livingstone, Edinburgh

38. Mehmet H, Yue X, Penrice J, Cady E, Wyatt JC, Sarraf C, Squier M, Edwards AD 1998 Relation of impaired energy metabolism to apoptosis and necrosis following transient cerebral hypoxia-ischaemia. Cell Death Differ 5:321-329

39. Varon S, McIlwain H 1961 Fluid content and compartments in isolated cerebral tissues. J Neurochem 8:262-275

40. Rolleston FS, Newsholme EA 1967 Control of glycolysis in cerebral cortex slices Biochem J 104:524-533

41. Tasker RC, Sahota SK, Williams SR 2000 Hypercarbia and mild hypothermia, only when not combined, improve postischaemic bioenergetic recovery in neonatal rat brain slices. J Cereb Blood Flow Metab 20:612-619

42. Thoresen M, Penrice J, Lorek A, Cady EB, Wylezinska M, Kirkbride V, Cooper CE, Brown GC, Edwards AD, Wyatt JS 1995 Mild hypothermia after transient hypoxiaischemia ameliorates delayed cerebral energy failure in the newborn piglet. Pediatr Res 37:667-670

43. Amess PN, Penrice J, Cady EB, Lorek A, Wylezinska M, Cooper CE, D'Souza P, Tyszczuk L, Thoresen M, Edwards AD, Wyatt JS, Reynolds EO 1997 Mild hypothermia after severe transient hypoxia-ischemia reduces the delayed rise in cerebral lactate in the newborn piglet. Pediatr Res 41:803-808

44. Busto R, Globus MY, Dietrich WD, Martinez E, Valdes I, Ginsberg MD 1989 Effect of mild hypothermia on ischemia-induced release of neurotransmitters and free fatty acids in rat brain. Stroke 20:904-910

45. Thoresen M, Satas S, Puka-Sundvall M, Whitelaw A, Hallstrom A, Loberg EM, Ungerstedt U, Steen PA, Hagberg H 1997 Post-hypoxic hypothermia reduces cerebrocortical release of NO and excitotoxins. Neuroreport 8:3359-3362

46. Chen Q, Chopp M, Bodzin G, Chen H 1993 Temperature modulation of cerebral depolarization during focal cerebral ischemia in rats: correlation with ischemic injury. J Cereb Blood Flow Metab 13:389-394

47. Edwards AD, Yue X, Squier MV, Thoresen M, Cady EB, Penrice J, Cooper CE, Wyatt JS, Reynolds EO, Mehmet H 1995 Specific inhibition of apoptosis after cerebral hypoxia-ischaemia by moderate post-insult hypothermia. Biochem Biophys Res Commun 26:1193-1199 
48. Laptook AR, Corbett RJ, Sterett R, Garcia D, Tollefsbol G 1995 Quantitative relationship between brain temperature and energy utilization rate measured in vivo using 31P and $1 \mathrm{H}$ magnetic resonance spectroscopy. Pediatr Res 38:919-925

49. Astrup J 1982 Energy-requiring cell functions in the ischemic brain. Their critical supply and possible inhibition in protective therapy. J Neurosurg 56:482-497

50. Siesjo BK, Bengtsson F 1989 Calcium fluxes, calcium antagonists, and calciumrelated pathology in brain ischemia, hypoglycemia, and spreading depression: a unifying hypothesis. J Cereb Blood Flow Metab 9:127-40

51. Traynelis SF, Cull-Candy SG 1990 Proton inhibition of $N$-methyl-D-aspartate receptors in cerebellar neurons. Nature 345:347-350

52. Giffard RG, Weiss JH, Choi DW 1992 Extracellular alkalinity exacerbates injury of cultured cortical neurons. Stroke 23:1817-1821

53. Mellgren RL 1987 Calcium dependent proteases: an enzyme system active at cellular membranes? FASEB J 1:110-115

54. Phillis JW, Ren J, O'Regan $\mathrm{MH} 2000$ Inhibition of $\mathrm{Na}(+) / \mathrm{H}(+)$ exchange by 5 -(N-ethyl-N-isopropyl)-amiloride reduces free fatty acid efflux from the ischemic reperfused rat cerebral cortex. Brain Res 884:155-162
55. Khaled AR, Kim K, Hofmeister R, Muegge K, Durum SK 1999 Withdrawal of IL-7 induces Bax translocation from cytosol to mitochondria through a rise in $\mathrm{pH}$. Proc Natl Acad Sci USA 96:14476-14481

56. Khaled AR, Reynolds DA, Young HA, Thompson CB, Muegge K, Durum SK 2001 Interleukin-3 withdrawal induces an early increase in mitochondrial membrane potential unrelated to the Bcl-2 family. Roles of intracellular $\mathrm{pH}$, ADP transport and $\mathrm{F}_{\mathrm{O}} \mathrm{F}_{1}$-ATPase. J Biol Chem 276:6453-6462

57. Lemasters JJ, Nieminen AL, Qian T, Trost LC, Herman B 1997 The mitochondrial permeability transition in toxic, hypoxic and reperfusion injury. Mol Cell Biochem 174:159-165

58. Yamamoto S, Matsumoto Y, Suzuki Y, Tsuboi T, Terakawa S, Ohashi N, Umemura $\mathrm{K} 2003 \mathrm{An} \mathrm{Na}{ }^{+} / \mathrm{H}^{+}$exchanger inhibitor suppresses cellular swelling and neuronal death induced by glutamate in cultured cortical neurons. Acta Neurochir Suppl $86: 223-226$

59. Manev H, Bertolino M, DeErausquin G 1990 Amiloride blocks glutamate-operated cationic channels and protects neurons in culture from glutamate-induced death. Neuropharmacology 29:1103-1110 